\title{
Efektivitas Ekstrak Etanol Daun Jeruk Purut (Citrus hystrix DC) Sebagai Larvasida Nyamuk Aedes aegypti
}

\author{
Esy Maryanti ${ }^{1}$, R. Della marta ${ }^{2}$, M.Yulis Hamidy ${ }^{3}$
}

\begin{abstract}
Dengue Hemorrhagic Fever is caused by dengue virus and spread by Aedes aegypti as primarily vector. Preventing dengue virus transmission depends on control of the mosquito vectors. Kiffer lime is one of the potential plants as a botanical larvacidal. The aim of this study was to investigate kiffer lime larvacidal ability against Ae.aegypti larvae based on $\mathrm{LC}_{50}$ and $\mathrm{LC}_{90}$ levels by probit analize. The design of this research was experimental including preliminary test and final test. 525 samples of Ae.aegypti larvae instar III/IV were used in this study and divided in to six groups of experiment. The result were from observation of the larvae mortalities within 24 hours. Assassement of larvacidal efficacy demonstrated that kiffer lime leaf were toxic against Ae.aegypti larvae. LC $_{50}$ value is 4015,880 ppm and LC value is $6961,822 \mathrm{ppm}$. Ethanol extract of kiffer lime leaf could be considered as a potentially alternative source for botanical larvacides.
\end{abstract}

Keywords: larvacides, kiffer lime, Aedes aegypti

Demam Berdarah Dengue (DBD) adalah penyakit infeksi yang disebabkan oleh virus dengue dan ditularkan oleh nyamuk Ae.aegypti sebagai vektor utama. Kriteria klinis infeksi virus dengue menurut World Health Organization (WHO) adalah panas tinggi mendadak, manifestasi perdarahan, tes Rumple Leede positif dan hepatomegali. ${ }^{1}$

Selama 50 tahun terakhir, insiden DBD terus meningkat hingga 30 kali lipat. Diperkirakan 2,5 milyar populasi dunia menetap di daerah endemis DBD dengan 50 juta infeksi dengue terjadi setiap tahunnya. Asia Tenggara dan Pasifik Barat merupakan daerah yang mengalami dampak paling serius berupa kematian akibat DBD. ${ }^{1}$ Total kasus DBD di Asia Tenggara tahun 2010 hingga bulan September sebanyak 187.333 kasus. Tahun 2010 di Indonesia, jumlah kasus DBD dilaporkan sebanyak 80.065 kasus dengan Case Fatality Rate (CFR) $0,93 \% .{ }^{2}$ Penyakit DBD juga menjadi masalah kesehatan di Provinsi Riau. Sebanyak 1.603 kasus

\footnotetext{
Penulis untuk korespendensi : Bagian Parasitologi Fakultas Kedokteran Universitas Riau J1. Diponegoro no 1 Pekanbaru e-mail: esy.maryanti@gmail.com

2 Mahasiswa Fakultas Kedokteran Universitas Riau

3 Bagian Farmakologi Fakultas Kedokteran Universitas Riau.
}

DBD dengan Incidence Rate (IR) 30,21/100.000 penduduk dilaporkan pada tahun 2009. ${ }^{3}$ Data dari Dinas Kesehatan Kota Pekanbaru tahun 2009 terdapat sebanyak 397 kasus DBD dengan lima orang meninggal dengan IR 49,43/100.000 penduduk. Pada tahun 2010 tercatat 196 kasus dan satu orang meninggal dengan kasus tertinggi terdapat di Kecamatan Bukit Raya yaitu sebanyak 38 kasus. $^{4}$

Pemerintah Indonesia terus berusaha memperbaiki program pemberantasan DBD yang terdiri dari tiga hal yaitu peningkatan kegiatan surveilens penyakit dan vektor, diagnosis dan pengobatan dini, serta peningkatan upaya pemberantasan vektor. ${ }^{5,6}$ Pemberantasan vektor DBD dapat dilakukan secara mekanik, kimiawi, dan biologis yang bertujuan untuk mengurangi populasi vektor. Pengendalian vektor yang sering dilakukan pada saat ini adalah dengan metode kimia (pengasapan dan larvasida). Pengendalian secara kimia ini memiliki dampak negatif seperti menimbulkan pencemaran lingkungan, keracunan, kematian organisme bukan sasaran, menghasilkan residu dan resistensi. ${ }^{7}$ 
Banyaknya kerugian yang ditimbulkan oleh larvasida kimia maka perlu suatu usaha untuk mendapatkan suatu aternatif dalam mengendalikan populasi vektor, salah satunya dengan menggunakan larvasida alami. Larvasida alami mengandung bahan yang mudah dan cepat terdegradasi di alam. ${ }^{8}$

Larvasida nabati yang berasal dari tumbuhan telah banyak diteliti, salah satunya adalah jeruk purut (Citrus hystrix DC). Jeruk purut merupakan salah satu spesies dari famili Rutaceae. Komponen minyak atsiri dari famili tersebut memiliki potensi sebagai insektisida alternatif. Daun jeruk purut memiliki kandungan minyak atsiri, tannin dan triterpenoid yang merupakan senyawa bioaktif larvasida. ${ }^{9,10}$

Beberapa penelitian mengenai efektivitas jeruk purut sebagai larvasida dan repelen pernah dilakukan oleh Tawatsin dkk (2001) yaitu mengenai efektivitas minyak atsiri kulit buah jeruk perut sebagai repelen terhadap nyamuk Ae.aegypti. Hasil penelitian menunjukan bahwa kulit buah jeruk purut mampu melindungi dari gigitan nyamuk $3-4,5$ jam. ${ }^{11}$ Penelitian Sutthanont dkk (2010) mengenai efektivitas minyak atsiri dari beberapa tanaman salah satunya Citrus hystrix sebagai larvasida nyamuk Ae.aegypti, didapatkan bahwa kulit dan buah jeruk purut memiliki kandungan minyak atsiri tertinggi. ${ }^{12}$ Penelitian Hayati (2008) mengenai efektivitas air perasan daun jeruk purut terhadap kematian larva nyamuk Ae.aegypti memberikan hasil $\mathrm{LC}_{90}$ terletak pada konsentrasi $12,5 \% .{ }^{13}$ Daun jeruk purut juga memiliki kandungan tannin dan triterpenoid yang berpotensi sebagai larvasida seperti yang telah dibuktikan oleh Yunita dkk (2009) pada penelitian uji komposisi tannin dan terpenoid pada ekstrak etanol daun teklan (Eupatorium riparium) dan efek toksiknya terhadap mortalitas larva Ae.aegypti. Ekstrak tersebut mampu menyebabkan kematian sebesar $81,25 \%$ pada konsentrasi $0,02 \%$ dan mematikan $100 \%$ larva pada konsentrasi $0,04 \%, 0,08 \%$ dan 0,1\%.8,9

Kelarutan senyawa bioaktif dari suatu tanaman ditentukan oleh jenis sediaan bahan uji serta pemilihan cairan penyari yang tepat. Kandungan senyawa bioaktif pada daun jeruk purut khususnya minyak atsiri akan lebih baik kelarutannya jika menggunakan etanol. ${ }^{14}$ Uji efektivitas larvasida daun jeruk purut menilai derajat ketoksikan dari pemaparan ekstrak tersebut terhadap larva uji yang diberikan selama 24 jam dengan $\mathrm{LC}_{50}$ sebagai tolak ukur kuantitatif. ${ }^{15}$ Berdasarkan hal tersebut dilakukan penelitian uji efektivitas larvasida ekstrak etanol daun jeruk purut (Citrus hystrix DC) terhadap larva nyamuk Ae.aegypti. Adapun tujuan dari penelitian ini yaitu melihat efektivitas larvasida ekstrak etanol daun jeruk purut (Citrus hystrix DC) serta mengetahui berapa konsentrasi ekstrak etanol daun jeruk purut yang diperlukan untuk membunuh $50 \%$ larva (Lethal Concentration ${ }_{50} / \mathrm{LC}_{50}$ ) dan $90 \%$ larva (Lethal Concentration ${ }_{90} / \mathrm{LC}_{90}$ ).

\section{METODE}

Penelitian dilaksanakan di Laboratorium Penelitian Sekolah Tinggi Ilmu Farmasi (STIFAR) dan Laboratorium Parasitologi Fakultas Kedokteran Universitas Riau pada bulan Desember 2010 - Maret 2011. Penelitian ini bersifat eksperimental, terdiri dari uji pendahuluan dan uji akhir. Uji pendahuluan dilakukan untuk mengetahui kisaran konsentrasi yang digunakan pada uji akhir. Uji pendahuluan dilakukan pengulangan tiga kali dengan dua replikasi dan uji akhir dilakukan pengulangan sebanyak tiga kali dengan tiga replikasi.

Uji pendahuluan menggunakan delapan kelompok yang terdiri dari tujuh kelompok perlakuan dengan varian konsentrasi $250 \mathrm{ppm}, 500$ ppm, 1000 ppm, 2000 ppm, 4000 ppm, 6000 ppm dan $8000 \mathrm{ppm}$. Uji akhir menggunakan tujuh kelompok yang terdiri dari enam kelompok perlakuan dengan varian konsentrasi $500 \mathrm{ppm}, 1000$ ppm, 2000 ppm, 4000 ppm, 6000 ppm dan 8000 ppm. Setiap uji disertakan satu kelompok kontrol negative (aquadest). Variabel bebas adalah konsentrasi ekstrak etanol daun jeruk purut dan variabel terikatnya adalah kematian larva nyamuk Ae.aegypti pada $\mathrm{LC}_{50}$ dan $\mathrm{LC}_{90}$.

Alat dan bahan yang digunakan dalam penelitian ini adalah oven pengering, blender, botol kaca berwarna gelap, gelas ukur $1000 \mathrm{cc}$, corong penyaring, kapas saring, batang pengaduk kaca, spatula, labu $1000 \mathrm{~mL}$, rotary evaporator, cawan pengering, botol kaca $50 \mathrm{~mL}$ berwarna gelap, botol plastik, pipet plastik, kertas label, senter, mikroskop, preparat kaca, termometer, kawat nyamuk, kain kasa, baki plastik, pH meter, baki plastik 30x20x5, 
daun jeruk purut, etanol 96\%, Tween 20 0,2\%, larva Ae.aegypti, makanan ikan, kapas madu, dan aquades

Daun jeruk purut yang digunakan adalah daun yang utuh dan berwarna hijau tua sebanyak $2 \mathrm{~kg}$. Daun dimasukkan ke dalam oven pengering untuk dilakukan pengeringan di dalam ruangan tanpa terpapar sinar matahari langsung. Pengeringan dilakukan selama dua hari hingga diperoleh simplisia sebanyak 750 g. Simplisia kemudian diblender, bubuk yang didapat diekstraksi dengan metode maserasi menggunakan pelarut etanol $96 \%$ hingga seluruh simplisia terendam dengan perbandingan 1:10. Selama proses maserasi dilakukan pengadukan untuk mempercepat pelarutan zat. Endapan yang diperoleh dipisahkan dan filtratnya dipekatkan. Proses ini kemudian dilanjutkan pemisahan ekstrak dari pelarutnya dengan pemanasan dan pemekatan yang dipercepat dengan putaran rotary evaporator selama 24 jam hingga diperoleh ekstrak kental daun jeruk purut sebanyak $108 \mathrm{~g}$.

Larva yang digunakan pada penelitian ini adalah larva Ae.aegypti instar III/IV generasi pertama yang diturunkan dari larva yang diperoleh dari Tempat Penampungan Air (TPA) rumah penduduk di Kecamatan Bukit Raya Pekanbaru. Jumlah larva Ae.aegypti yang diperlukan untuk uji pendahuluan adalah 10 ekor dan untuk uji akhir adalah 25 ekor larva untuk setiap kelompok. Total jumlah larva larva Ae.aegypti yang dibutuhkan pada uji pendahuluan dengan dua replikasi adalah 320 ekor dan untuk uji akhir dengan tiga replikasi adalah sebanyak 525 ekor.

Larva diambil satu ekor dengan menggunakan pipet plastik secara single larva method yang artinya jika di dalam sebuah TPA ditemukan satu ekor larva Ae.aegypti maka dianggap keseluruhan larva yang terdapat di dalam TPA tersebut adalah Ae.aegypti. Larva di masukkan ke dalam botol yang diberi label sesuai dengan TPA tempat larva tersebut diambil. Larva tersebut diidentifikasi spesiesnya di Laboratorium Parasitologi Fakultas Kedokteran Universitas Riau (FK UR). Larva yang belum mencapai tingkatan instar III/IV, telah berubah menjadi pupa, tidak sehat atau mati dikeluarkan dari kontainer dan diganti.
Penggunaan larva generasi pertama dimaksudkan agar sifatnya homogen sesuai dengan standar yang ditetapkan WHO. Larva dimasukkan ke dalam gelas plastik yang berisi aquadest. Kondisi laboratorium disesuaikan dengan kondisi lingkungan optimal yang dibutuhkan larva agar tetap hidup dan tumbuh dengan baik, yaitu temperatur ruangan $25 \pm 2^{\circ} \mathrm{C}$, temperatur air $25-28^{\circ} \mathrm{C}$, dan $\mathrm{pH}$ air $7 .{ }^{15,16}$ Larva dipelihara hingga mencapai tahap pupa. Selama proses metamorfosis menjadi pupa, larva diberi makan berupa pelet ikan yang telah dihaluskan dengan interval satu hari. ${ }^{15}$ Setelah larva mencapai bentuk pupa, larva dipindahkan ke dalam baki plastik berukuran $30 \times 20 \times 5 \mathrm{~cm}$ yang berisi aquadest yang terdapat di kandang nyamuk. Nyamuk betina gravid harus memiliki nutrisi yang cukup untuk perkembangan telurnya oleh karena itu diperlukan darah. Pada penelitian ini digunakan darah manusia yaitu tangan peneliti dimasukkan ke dalam lubang yang terdapat di kandang sebagai media penghisapan darah bagi nyamuk. Baki yang terdapat di dalam kandang juga diletakkan kain kasa pada semua sisinya sebagai tempat meletakkan telur. Telur-telur dibiarkan menetas dan tumbuh mencapai tahap larva instar III dan IV yang akan digunakan pada uji akhir.

Tujuan dilakukan uji pendahuluan adalah untuk mendapatkan rentang konsentrasi ekstrak etanol daun jeruk purut yang dapat mematikan larva Ae.aegypti. Larutan kerja yang digunakan adalah $250 \mathrm{ppm}, 500 \mathrm{ppm}, 1000 \mathrm{ppm}, 2000$ ppm, 4000ppm, 6000 ppm dan 8000 ppm. Kisaran konsentrasi ini dipilih karena dapat menyebabkan kematian pada rentang 10\%-90\% larva. Larutan kerja diperoleh dari pengenceran larutan induk. Pada penelitian ini larutan induk yang digunakan adalah larutan dengan konsentrasi $10.000 \mathrm{ppm}$. Agar ekstrak etanol daun jeruk purut larut di dalam aquadest, terlebih dahulu ditambahkan Tween 20 0,2\% sebanyak 2 tetes sebagai homogenizer. Data hasil uji pendahuluan terlihat pada tabel 1 berikut ini: 
Tabel 1 Jumlah kematian larva dari hasil uji pendahuluan

\begin{tabular}{|c|c|c|c|c|c|c|c|c|c|}
\hline \multirow{2}{*}{ U1angan } & \multirow{2}{*}{$\begin{array}{l}\text { Jumlah } \\
\text { larva }\end{array}$} & \multicolumn{8}{|c|}{ Konsentrasi ekstrak dan jumlah kematian larva } \\
\hline & & $\begin{array}{l}250 \\
\text { ppm }\end{array}$ & $\begin{array}{l}500 \\
\mathrm{ppm}\end{array}$ & $\begin{array}{l}1000 \\
\mathrm{ppm}\end{array}$ & $\begin{array}{l}2000 \\
\mathrm{ppm}\end{array}$ & $\begin{array}{l}4000 \\
\mathrm{ppm}\end{array}$ & $\begin{array}{l}6000 \\
\mathrm{ppm}\end{array}$ & $\begin{array}{l}8000 \\
\mathrm{ppm}\end{array}$ & $\mathrm{K}$ ontrol \\
\hline I & 10 & 0 & 0 & 1 & 2 & 6 & 8 & 9 & $0 \%$ \\
\hline II & 10 & 0 & 1 & 2 & 3 & 5 & 8 & 10 & $0 \%$ \\
\hline \multicolumn{2}{|c|}{$\begin{array}{c}\text { Rerata } K \text { ematian } \\
(\%)\end{array}$} & 0 & 5 & 15 & 25 & 55 & 80 & 95 & 0 \\
\hline
\end{tabular}

Berdasarkan hasil uji pendahuluan yang telah dilakukan maka ditetapkan konsentrasi ekstrak etanol daun jeruk purut yang digunakan pada uji akhir adalah 500 ppm, 1000 ppm, 2000 ppm, 4000 ppm, $6000 \mathrm{ppm}$ dan $8000 \mathrm{ppm}$ karena dapat menyebabkan kematian 10\% - 90\% larva.

Pengumpulan data hasil penelitian dilakukan 24 jam setelah pemaparan. Larva yang sudah mati merupakan larva yang tidak dapat bergerak ketika sifon atau daerah servikalnya disentuh dengan batang pengaduk. Larva yang hampir mati adalah larva yang sudah tidak sanggup lagi berenang ke permukaan air atau menunjukkan reaksi menyelam ke dasar wadah ketika gelas plastik diganggu. Data hasil penelitian dianalisis menggunakan analisis regresi probit untuk menentukan $\mathrm{LC}_{50}$ dan $\mathrm{LC}_{90}$. Jika kematian larva pada kelompok kontrol kurang dari $5 \%$ diabaikan, lebih dari $20 \%$ diuji ulang dan jika antara 5-20\% maka angka kematian larva nyamuk pada masing-masing konsentrasi harus dikoreksi dengan formula Abbott. ${ }^{15}$

\section{HASIL}

Hasil penelitian efektivitas ekstrak etanol daun jeruk purut (Citrus hystrix DC) sebagai larvasida nyamuk Ae.aegypti disajikan pada Tabel 2 berikut:

Tabel 2. Jumlah dan persentase larva Ae.agypti yang mati pada berbagai perlakuan ekstrak etanol daun jeruk purut

\begin{tabular}{|c|c|c|c|c|c|c|c|c|}
\hline \multirow[b]{2}{*}{ Hari } & \multirow[b]{2}{*}{ Replikasi } & \multicolumn{7}{|c|}{$\begin{array}{l}\text { Jumlah kemati an larva pada berbagai konsentrasi (ppm) } \\
\text { Setelah } 24 \text { jam pemap aran }\end{array}$} \\
\hline & & $\begin{array}{l}500 \\
\text { ppm }\end{array}$ & $\begin{array}{l}1000 \\
\text { ppm }\end{array}$ & $\begin{array}{l}2000 \\
\mathrm{ppm}\end{array}$ & $\begin{array}{r}4000 \\
P p m\end{array}$ & $\begin{array}{l}6000 \\
\mathrm{ppm}\end{array}$ & $\begin{array}{l}8000 \\
\text { ppm }\end{array}$ & $\begin{array}{l}\text { Kontrol } \\
\text { negatif }\end{array}$ \\
\hline \multirow[t]{3}{*}{ I } & 1 & 1 & 3 & 7 & 15 & 19 & 23 & 0 \\
\hline & 2 & 0 & 2 & 6 & 13 & 19 & 24 & 0 \\
\hline & 3 & 0 & 3 & 6 & 14 & 20 & 22 & 0 \\
\hline \multirow[t]{3}{*}{ III } & 1 & 1 & 2 & 6 & 15 & 19 & 23 & 1 \\
\hline & 2 & 0 & 2 & 8 & 13 & 20 & 24 & 0 \\
\hline & 3 & 0 & 4 & 7 & 15 & 20 & 23 & 0 \\
\hline \multirow[t]{6}{*}{ VI } & 1 & 1 & 2 & 6 & 13 & 21 & 22 & 0 \\
\hline & 2 & 1 & 2 & 7 & 14 & 20 & 24 & 0 \\
\hline & 3 & 0 & 3 & 7 & 14 & 21 & 24 & 1 \\
\hline & $\begin{array}{l}\text { Total } \\
\text { (ekor) }\end{array}$ & 4 & 23 & 60 & 126 & 179 & 209 & 2 \\
\hline & Rerata & 0,44 & 2,56 & 6,67 & 14 & 19,89 & 23,22 & 0,22 \\
\hline & $\begin{array}{c}\% \% \\
\text { kematian }\end{array}$ & 1,78 & 10,22 & 26,67 & 56 & 79,56 & 92,89 & 0,89 \\
\hline
\end{tabular}


Berdasarkan Tabel 2 terlihat bahwa konsentrasi ekstrak etanol daun jeruk purut $8000 \mathrm{ppm}$ menunjukkan jumlah kematian yang paling besar, diikuti konsentrasi 6000 ppm, 4000 ppm, 2000 ppm, 1000ppm dan 500 ppm.
Data primer dari hasil penelitian dianalisis menggunakan analisis probit untuk mendapatkan $\mathrm{LC}_{50}$ dan $\mathrm{LC}_{90}$ ekstrak etanol daun jeruk purut terhadap larva Ae.aegypti, seperti terdapat pada tabel 3:

Tabel 3. LC50 dan LC90 ekstrak etanol daun jeruk purut terhadap larva

\begin{tabular}{cl}
\hline $\mathrm{LC}_{90}(\mathrm{LB}-\mathrm{UB})$ & $\mathrm{LC} \mathrm{C}_{90}(\mathrm{LB}-\mathrm{UB})$ \\
\hline $4015,880 \mathrm{ppm}$ & $6961,833 \mathrm{ppm}$ \\
$(3407,534-4714,345 \mathrm{ppm})$ & $(6049,078-8366,248 \mathrm{ppm})$ \\
\hline
\end{tabular}

\section{PEMBAHASAN}

Berdasarkan hasil analisis probit, $\mathrm{LC}_{50}$ ekstrak etanol daun jeruk purut terletak pada konsentrasi 4015,880 ppm dan $\mathrm{LC}_{90} 6961,822 \mathrm{ppm}$. Ekstrak etanol daun jeruk purut dinyatakan efektif sebagai larvasida karena dapat membunuh larva Ae.aegypti. Terdapat $0,89 \%$ kematian pada kelompok kontrol, tetapi hal ini tidak bersifat toksik karena tidak mengandung bahan uji ekstrak etanol daun jeruk purut. Kematian tersebut kemungkinan disebabkan oleh trauma mekanis ketika larva diambil dengan pipet plastik. Persentase kematian kelompok kontrol yang 0,89\% tidak berada dalam rentang 5\%-20\% sehingga tidak perlu dikoreksi dengan formula Abbot. ${ }^{15}$

Bahan aktif yang diduga berperan sebagai larvasida pada daun jeruk purut diantaranya minyak atsiri, tannin dan triterpenoid. Senyawa-senyawa toksik tersebut menghasilkan efek resultan sebagai larvasida nyamuk Ae.aegypti. ${ }^{9}{ }^{10} \mathrm{Di}$ antara beberapa senyawa tersebut, minyak atsiri diduga sebagai bahan aktif yang paling dominan bekerja sebagai larvasida karena terdiri dari beberapa kandungan aktif, sifat-sifat terapeutik dan toksisitas minyak atsiri sebagian besar dimiliki oleh kandungankandungan tersebut. Kandungan utama minyak atsiri pada daun jeruk purut adalah golongan monoterpen seperti citronellal (85\%), citronellol (23,7\%), dan linalool $(5,2 \%) .{ }^{17}$ Minyak atsiri golongan monoterpen bersifat toksik terhadap sistem saraf dengan mekanisme kerja menghambat asetilkolinesterase larva sehingga terjadi kekacauan sistem penghantaran impuls. Minyak atisri juga mempengaruhi fungsi octopamine. Octopamine merupakan neurotransmitter pada larva yang juga memiliki fungsi sebagai neurohormon dan neuromodulator. Penghambatan pada octapamine menyebabkan gangguan pada sistem saraf larva sehingga larva akan mati. Secara khas, racun saraf menimbulkan empat tahap gejala yaitu eksitasi, konvulsi, paralisis dan kematian pada hewan uji. ${ }^{10,18}$

Hasil analisis probit uji akhir ekstrak etanol daun jeruk purut terhadap larva Ae.agypti $\mathrm{LC}_{50}$ terletak pada konsentrasi 4015,880 ppm dan $\mathrm{LC}_{90}$ pada konsentrasi 6961,822 ppm. Hasil ini berbeda dengan penelitian Hayati dkk (2009) tentang efektivitas perasaan daun jeruk purut terhadap larva Ae.aegypti. Hayati dkk memperoleh kematian $90 \%$ larva pada konsentrasi $12,5 \% .{ }^{13}$ Penelitian Hayati jika dibandingkan dengan penelitian ini berbeda pada sediaan yang digunakan. Jika hasil penelitian efektivitas daun jeruk purut dikonversikan ke persen (\%) maka $\mathrm{LC}_{90}$ yang terletak pada 6961,822 ppm sama dengan $0,69 \%$ yang artinya daun jeruk yang diekstraksi lebih efektif sebagai larvasida dibandingkan dengan sediaan air perasan. Penelitian mengenai efektivitas ekstrak jeruk purut sebagai larvasida belum banyak dilakukan, tetapi isolasi kandungan minyak atsiri yang terdapat pada kulit dan buah jeruk purut sudah banyak dilakukan.

Bahan aktif lainnya yang diduga memiliki aktivitas larvasida adalah tannin dan triterpenoid. Efek toksik tannin dan triterpenoid terhadap larva Ae.aegypti telah dibuktikan oleh Yunita dkk (2009) pada daun teklan (Eupatorium riparium) dimana konsentrasi yang efektif membunuh 50\% larva adalah $0,014 \%$. Tannin dan triterpenoid menyebabkan penekanan pada konsumsi makan, 
tingkat pertumbuhan dan kemampuan bertahan larva. Pada uji subletal penelitian Yunita dkk menunjukkan ekstrak mampu menurunkan persentase pertumbuhan larva menjadi pupa. Pemberian ekstrak E. riparium dengan konsentrasi yang semakin meningkat dapat menekan keberhasilan larva yang menjadi pupa. ${ }^{8}$ Pada penelitian ini, meskipun tidak diteliti hubungan pemberian dosis dengan keberhasilan larva menjadi pupa, dapat terlihat pada semua kelompok uji adanya penghambatan pertumbuhan pada larva, berbeda dengan kelompok kontrol yang setelah 24 jam ditemukan larva yang telah berubah menjadi pupa.

Penelitian ini menggunakan larva uji Ae.agypti generasi pertama. WHO mengatur penggunaan larva generasi pertama untuk uji efikasi larvasida karena kondisinya yang telah homogen. Larva dipelihara di lingkungan dan makanan yang sama serta bebas dari pengaruh insektisida atau zat-zat kimia. ${ }^{15}$ Larva generasi pertama dipelihara dengan kondisi laboratorium yang disarankan oleh WHO agar larva dapat tumbuh dengan baik. Larva cocok hidup di lingkungan dengan suhu ruangan $25 \pm 2^{\circ} \mathrm{C}$, temperatur air antara $25-28^{\circ} \mathrm{C}$ dan $\mathrm{pH}$ air $7 .{ }^{15,16} \mathrm{Pada}$ penelitian ini suhu ruangan pada saat uji pendahuluan maupun uji akhir berkisar antara 25$28^{\circ} \mathrm{C}$ yang diukur dengan menggunakan termometer ruangan. Suhu dan $\mathrm{pH}$ air juga diperhatikan, pada penelitian ini suhu air dijaga pada kisaran $25-28^{\circ} \mathrm{C}$ dengan pH 7. Sukamsih (2006) meneliti tentang pengaruh berbagai $\mathrm{pH}$ air terhadap kehidupan larva nyamuk Ae.aegypti. Melalui penelitian ini diketahui bahwa pH 7 merupakan pH optimum untuk perkembangan larva dibandingkan air dengan $\mathrm{pH}$ asam atau basa. ${ }^{16}$

Selain kondisi lingkungan, makanan juga turut mempengaruhi perkembangan larva. Pada penelitian ini, makanan yang diberikan kepada larva berupa pelet ikan yang digerus halus dan diberikan dengan interval satu hari sekali. Hal ini sesuai dengan protokol dari WHO yang mengatur bahwa pemberian makanan dilakukan dengan interval satu atau dua hari sekali. ${ }^{15}$

Larva instar III-IV yang dipilih pada penelitian ini juga telah disesuaikan dengan standar yang ditetapkan oleh WHO. Pemilihan instar tinggi disebabkan oleh sensitivitas setiap tingkatan instar berbeda-beda. ${ }^{15}$ Hal ini sudah dibuktikan oleh Sanjaya dkk (2006) melalui hasil penelitiannya yang menunjukkan semakin tinggi tingkat instar, semakin tinggi pula daya tahan hidupnya. Instar III dan IV merupakan instar dengan ketahanan tubuh terbaik. Perkembangan larva instar I-II belum optimal seperti instar III-IV, sehingga kemampuan untuk menetralisir senyawa yang bersifat toksik lebih rendah daripada larva instar III-IV. ${ }^{19}$

\section{KESIMPULAN}

Berdasarkan hasil penelitian uji efektivitas larvasida ekstrak etanol daun jeruk purut (Citrus hystrix DC) terhadap larva nyamuk Aedes aegypti dapat disimpulkan bahwa ekstrak etanol daun jeruk purut memiliki efek larvasida terhadap larva nyamuk Aedes aegypti. Konsentrasi ekstrak etanol daun jeruk purut yang diperlukan untuk membunuh 50\% populasi larva Aedes aegypti $\left(\mathrm{LC}_{50}\right)$ adalah 4015,880 ppm dan konsentrasi ekstrak etanol daun jeruk purut yang diperlukan untuk membunuh $90 \%$ populasi larva Aedes aegypti $\left(\mathrm{LC}_{90}\right)$ adalah 6961,822 ppm dalam jangka waktu 24 jam.

\section{SARAN}

Perlunya penelitian lebih lanjut untuk mengetahui senyawa aktif yang paling berperan sebagai larvasida dari daun jeruk purut. Selain itu, juga perlu dilakukan uji toksisitas ekstrak etanol daun jeruk purut terhadap hewan yang dipelihara di kolam atau tempat penampungan air lainnya dan manusia sebelum digunakan secara luas di masyarakat.

\section{DAFTAR PUSTAKA}

1. World Health Organization. Dengue guidelines for diagnosis, treatment, prevention and controlnew edition. 2009: 3-25.

2. World Health Organization. Situation update of dengue in the SEA region 2010. [cited 2010 Nov 9] Available from: http://www.searo.who.int/ LinkFiles/Dengue dengue-SEAR-2010.

3. Dinas Kesehatan Provinsi Riau. Profil kesehatan Provinsi Riau 2009. Pekanbaru: Dinas Kesehatan Provinsi Riau. 2009. 
4. Dinkes Kota Pekanbaru. Data Kasus DBD perkecamatan Kota Pekanbaru dari bulan januari hingga desember 2010. Pekanbaru: Dinas Kesehatan Kota Pekanbaru. 2010.

5. Sungkar S. Pemberantasan demam berdarah dengue: sebuah tantangan yang harus dijawab. Majalah Kedokteran Indonesia. 2007;57(6):16770.

6. Depkes Republik Indonesia. Profil kesehatan Indonesia 2008. Jakarta: Depkes RI; 2009 [Diakses tanggal 19 oktober 2010]. Diunduh dari: www.depkes.go.id/pdf.

7. Zulfiana D. Jamur pembunuh nyamuk DBD. Diterbitkan oleh: UPT Balai Litbang Biomaterial Lembaga Ilmu Pengetahuan Indonesia. 2009. [Diakses tanggal 26 oktober 2010]. Diunduh dari: http://www.biomaterial.lipi.go.id/

8. Yunita EA, Suprapti NH, Hidayat JW. Pengaruh ekstrak daun teklan (eupatorium riparium) terhadap mortalitas dan perkembangan larva Aedes aegypti. Bioma. 2009; 11(1):11-7.

9. Dalimartha S. Atlas tumbuhan obat Indonesia jilid 2. Jakarta: Trubus agriwidya; 2000.

10.Tripathi AK, Upadhyay S, Bhuiyan M, Bhattacharya PR. A review on prospects of essential oils as biopesticide in insect-pest management. $J$ of Pharmacognosy and Phytotherapy. 2009;1(5):52-63.

11. Tawatsin A, Wratten SD, Scott RR, Thavara U, Techadamrongsin Y. Repellency of volatile oils from plants against three mosquito vectors. J of Vector Ecology. 2001;26(1):76-82.

12. Sutthanont N, Choochote W, Tuetun B, Junkum A, Jitpakdi A, Chaithong U, et al. Chemical composition and larvicidal activity of edible plant-derived essential oils against the pyrethroid-susceptible and resistant strains of Aedes aegypti (Diptera: Culicidae). $\mathrm{J}$ of Vector Ecology. 2009;35(1):106-15.
13.Hayati N. Uji efikasi larvasida nabati dari perasan daun jeruk purut (Citrus hystrix DC) terhadap kematian larva Aedes aegypti di laboratorium B2V2VRP. [Skripsi]. Semarang: Universitas Muhammadiyah Semarang:2008.

14.Artikel Minyak Atsiri Indonesia. Minyak atsiri jeruk: peluang meningkatkan nilai ekonomi kulit jeruk. Warta penelitian dan pengembangan pertanian. 2008. 30(6) [diakses 19 oktober 2010]. Diunduh dari : http//:www. minyakatsiri indonesia.com

15. World Health Organization. Guidelines for laboratory and field testing of mosquito larvicides. WHO: Communicable disease control, prevention and eradication, WHO pesticide evaluation scheme. 2005: 5-39.

16.Sukamsih. Perbedaan berbagai $\mathrm{pH}$ air terhadap kehidupan larva nyamuk Aedes aegypti di laboratorium balai besar penelitian vektor dan reservoir penyakit salatiga tahun 2005. [Skripsi]. Semarang: Universitas Diponegoro: 2006.

17.Fazwa F, Rasip A, Azah N, Said A, Mohamad O. Screeening of high genotype Citrus hystrix for essential oil production. J of essential oil research. 2000;8:627-32.

18.Isman MB. Plant essential oils for pest and disease management. Crop protection. 2000;19: 603-8.

19.Sanjaya Y, Safaria T. Toksisitas racun laba-laba Nephila sp. Pada larva Aedes aegypti L. Biodiversitas. 2006; 7(2): 191-4. 